\title{
Future-Generation Perception: Equal or Not Equal? Long-Term Individual Discount Rates for Poland
}

\author{
Monika Foltyn-Zarychta (D)
}

Citation: Foltyn-Zarychta, M. Future-Generation Perception: Equal or Not Equal? Long-Term Individual Discount Rates for Poland. Energies 2021, 14, 8218. https://doi.org/ $10.3390 /$ en14248218

Academic Editor: Frede Blaabjerg

Received: 9 November 2021

Accepted: 3 December 2021

Published: 7 December 2021

Publisher's Note: MDPI stays neutral with regard to jurisdictional claims in published maps and institutional affiliations.

Copyright: (C) 2021 by the author. Licensee MDPI, Basel, Switzerland. This article is an open access article distributed under the terms and conditions of the Creative Commons Attribution (CC BY) license (https:// creativecommons.org/licenses/by/ $4.0 /)$.
Department of Investment, Faculty of Finance, University of Economics in Katowice, 40-287 Katowice, Poland; monika.foltyn-zarychta@uekat.pl

\begin{abstract}
Energy-related investments gain increasing attention nowadays, particularly in Poland due to clean-energy investment needed to limit greenhouse gas emissions (GHG) and counteract climate change. However, economic appraisal is problematic: the longevity of impacts inextricably involves intergenerational ethical considerations. A crucial parameter is the choice of a discount rate. The predominant approach to estimate the discount rate in EU countries is the Ramsey rule, based on macroeconomic data, but not referring directly to society's preferences. Those are considered by studies using surveys to elicit individual discount rates (IDR), but rarely concentrating on intergenerational time frame. The paper aims at delivering an insight into the intergenerational intertemporal preferences for Poland (households, $n=471$ ) focusing on whether respondents are willing to declare zero discount rate intergenerationally and whether their choices differ between the short- and long-term perspectives and between human lives and money. To elicit IDR, two hypothetical investment scenarios were designed: lifesaving programs and lottery gains with delays from 10 to 150 years accompanied by attitude and socioeconomic questions. The results indicate that IDR follows hyperbolic time-decline, and a considerable share of respondents (around 20\%) are willing to treat future generations as equally important in the case of human lives, while this proportion for monetary gains is two times lower. The IDR drivers differ between lives and money in respect of socioeconomic profile and attitude characteristics as well as between intragenerational and intergenerational time frames. The findings support (a) the rationale for distinct treatment of intergenerational allocations, (b) the divergence of preferences between public and private impacts, and (c) the switch from single to declining discount rate regime in Poland.
\end{abstract}

Keywords: energy policy and investments; economic appraisal; intergenerational justice; individual discount rate; climate change

\section{Introduction}

Economic appraisal of energy-related policies and investments is a particularly difficult task due to several reasons, including the substantiality of initial outlays for infrastructure, various externalities, and, last but not least, the longevity of the impacts. The time component in the analysis is usually dealt with by discounting future benefits, which makes them economically equivalent to present-day outlays, allowing comparisons and selection of projects with positive net present benefits.

A predominant approach to estimate discount rate for economic evaluation in the European Union (EU) is the Ramsey formula, where the rate is calculated as the sum of pure time preference (utility discount rate) representing society's impatience and the society consumption opportunity cost, which is a product of expected growth rate of per capita consumption and the elasticity of marginal utility of consumption [1]. The Ramsey rule is the basis for discounting in the EU economic appraisal guidelines, i.e., recommending for CEE countries like Poland a single rate of $5 \%$ in the previous cohesion policy programming period, 2014-2020 [2].

However, a single rate application may lead to the danger of a deep imbalance between short-term and long-term outcome comparison. The investment benefits or costs that emerge 
far in the future, when discounted at the rate of 5\%, turn insignificant in the evaluation when compared with short-term impacts ( 1 million of benefit received after 30 years diminishes to $23 \%$; after 50 years, it shrinks to approximately $9 \%$; after 100 years, it is less than $1 \%$ of the initial value). The choice of a discount rate can therefore be decisive for the evaluation outcome for energy policies and investments due to the fact that a considerable share of their impact reaches far in time. This is of particular importance when public funds are invested. Since the funds are limited, the appropriate discount rate ensures that the outlays will be dedicated to the best available energy investment option allowing for the maximum well-being increase.

\subsection{Energy Policy Investments-The Longevity and Heterogeneity of Impacts and the Ethical Implications}

Of tremendous importance for energy-related policies and investments is the fact that they usually generate significant impacts for long-term. Most of those impacts are publictype externalities. This calls to be addressed separately from intragenerational context [3]. In the case of Poland, several areas crucial for energy policy can be stressed in relation to intergenerational issues.

First, the significant level of investment needs. Energy production in Poland is heavily based on coal: around 70\% of primary energy production comes from solid fossil fuels [4], and the country is among the top $\mathrm{CO}_{2}$ emitters in the EU [5]. This calls for substantial investment effort in reducing the GHG emissions by switching to clean sources of energy. Polish energy policy (PEP) to 2030 assumes that the share of hard coal in electricity generation will not be higher than 56\% and renewable energy sources' (RES) share in final energy consumption will not be less than $23 \%$. Primary energy consumption will decrease by $23 \%$ and will result in a $30 \%$ reduction in GHG emissions compared to 1990 emissions [6]. However, up to 2050 further efforts are required due to the need to meet the EU carbon-neutrality goals [7]. The estimates for investment outlays necessary to achieve those targets reach EUR 60-70 billion by 2030 and additional EUR 130-175 billion up to 2050 [8].

Second are the plans to balance RES in the energy mix with nuclear energy. PEP assumes that nuclear energy will be implemented by 2033 [6] and the Polish nuclear power program (PNPP) foresees that the first nuclear power plant will start to operate in 2040 and budgetary expenses in relation to nuclear policy implementations up to 2033 alone are estimated to reach nearly EUR 150 million [9].

Both investment areas mentioned above have multiple outcomes that should be appropriately considered in the economic evaluation. The primary characteristic of such investments is the longevity of the impacts. Although PEP has been elaborated up to 2040 [6], the climate and other environmental impacts will last intergenerationally. RES installations are usually estimated to have a life cycle of 20 to 40 years [10-12], depending on the type of the investment (wind or solar) and geographical location, but a longer time frame comes into play in the case of hydropower plants which may last 100 years $[13,14]$. Climate protection issues have perspectives ranging usually from 40 to 200 years [15,16], but in the case of determining the social cost of carbon they may reach 400 years [17-19] or 1000 years [20]. Nuclear energy timeframes vary, mostly depending on whether the radioactive waste management is considered. The operating time frame of a nuclear plant is estimated at around 40 years. However, the perspectives of waste management range start at 50-100 years $[17,21]$ and rise to thousands of years [19,22].

Apart from the extremely long-term perspective, energy-related investments bring heterogeneous impacts. Most of them fall into the domain of public goods, related to environmental goods but also increased mortality risks associated with climate warming $[23,24]$ or health-related hazards due to radioactivity [25]. However, some share of the outcomes is of private nature, i.e., PNPP raises the issue of the decrease in the electricity prices for households and improvement of the competitiveness of Polish enterprises on the domestic and international market [9].

The nature of those impacts poses a range of ethical considerations. Climate change brings the issue of spatial and temporal inequality in adverse impact allocations, which will be 
mostly experienced by less-wealthy countries of the south and by the people who are not born yet [24]. The latter is also raised in connection with nuclear energy, i.e., International Atomic Energy Agency calls for limiting unnecessary burden imposed on future generations [26].

This intergenerational ethical puzzle is well described by Gardiner's phrase 'climate change is a perfect moral storm' [27] depicting the risks of the moral corruption toward future generations, who are not born yet and cannot influence today's actions with potentially irreversible impacts. In this context, the discounting procedure, due to its tremendous impact on present value calculations, in the intergenerational context should not be perceived as a standard tool for economic appraisal, but as a mechanism that poses a risk of intergenerational moral corruption. Caney, referring to discounting, asked whether it 'is appropriate to ascribe a lower weight to human interests the further they are in the future just because of the fact that they exist further in the future?' [28]. What should be also stressed is the fact that changing the decision time frame from intra- to intergenerational switches an individual decision from self-regarding domain (private) to other-regarding sphere (public) [29].

\subsection{Long-Term Discounting}

Considering the significant impact of a long-term perspective, particularly in the light of a growing need to act against climate change and carbon dioxide emissions, some countries, e.g., France or the UK, have applied declining discount rate frameworks [30,31] that reduce the imbalance between present and future allocations. The EU guidelines for economic appraisal allow each country to estimate their own discount rate values and while declining discount rates are mentioned (for projects over 50 years described as 'involving intergenerational equity considerations'), it recommends the use of the Ramsey-based single rate for reference period evaluations [32]. For the programming period 2014-2020, in the case of cohesion countries like Poland, the guidelines recommended 5\% [2], while for the next period (until 2027) they suggest using single rate of $3 \%$ in the absence of countryspecific recommendations. Even though there is some research on Poland-specific estimates (ranging 2.75-6.1\% with the majority of results slightly below 5\%, see [33-36]), the everyday practice in Poland to date has simply been to apply the EU single recommended rate of 5\% without any additional adjustments. What matters is that this solution is applied not only for the purpose of acquiring the EU cohesion funds, but also for other purposes, i.e., the Polish law on electromobility obliges local governments to carry out a cost-benefit analysis of switching to zero-emission buses in cities [37] and the majority of those appraisal reports apply the EU discount rate guidelines irrespectively of the EU funding perspectives [38].

This may potentially lead to underinvestment in energy-related sectors, which is of crucial importance for Poland already lagging behind in climate-related areas. The insufficient investment effort leads to higher electricity and heat prices due to the coaldependent energy generating system [4] facing increasing GHG emission prices as the EU emission trading system is entering the next stage in which the number of emission allowances will be reduced faster than previously [39]. Additionally, regarding growing consumer environmental awareness, too slowly changing the energy mix in Poland raises the risk of lower demand for Polish goods produced using coal-based electricity and therefore having higher carbon footprint, which could be easily noticed by consumers in the near future as the discourse of $\mathrm{CO}_{2}$ labelling is getting more and more attention [40].

The long-term perspective in the theory of the discount rate is dealt with using time declining rates. The Ramsey model is extended to include a precautionary term related to the risk toward level of future consumption [3,41,42]. Additionally, a project-related risk premium can be considered, based on the consumption Capital Asset Pricing Model (CAPM) [43]. This approach is applied, for example, for energy related and other long-term projects facing uncertainty $[44,45]$. However, the Ramsey model is not free from difficulties. The values given by the standard model rest heavily on future consumption predictions, which may lead to estimates unreasonably high or low in the intergenerational context. The IPCC 2014 report provided discount rate estimates for developed countries within the range of $3-5 \%$, while the discount rate for China is $15 \%$ and $-5.52 \%$ for the Democratic Republic 
of Congo [46]. A separate point is the discourse over the pure time preference rate (utility discount rate) element: whether it should represent a descriptive value, given e.g., by the population's annual death rate, or chances for human extinction which gives a positive value of the rate [15] or whether it should be based on ethical basis arguing for zero utility discount rate $[28,47]$.

Discounting in economic appraisal can also be derived from the social opportunity cost of capital and the consumption rate of interest, which both reflect market rates (private sector or consumers' rates of returns on investments). The empirical estimates use financial market rates, i.e., the real before-tax rate of return on corporate bonds or national account data to assess the private sector contribution to GDP $[34,48,49]$. The estimates for developed countries are usually higher than Ramsey's (i.e., Spackman's recent estimates are of 6-8\% [49]). However, for the long-run intergenerational perspective this approach — based on the market observed choices-has a limited usefulness due to the lack of long-term market data (over 30-years) and the myopia of financial markets [18].

The third stream of studies concentrates on deriving individual discount rates based on the willingness to pay for a given outcome delayed in time, backed by contingent valuation methodology [50]. The studies represent a wide array of approaches: experiments [51-53], household surveys [54,55], or expert opinions [56-58]. The authors apply various delays, from short-term, e.g., months [55], to decades [59] and centuries [51-54]. They elicit bids for various types of delayed impacts: human lives [53,54], health [59], money [52,60], environmental assets [51,61], consumer goods [62]. Some researchers additionally investigate the socioeconomic drivers of discount rates, such as: gender, age, income, education, children, family size, e.g., $[54,55,63]$ and analyze interdependencies between discount rates and beliefs or attitudes, e.g., perceived importance of environment, donations for social activities [55,61]. The values given by implicit discount rates tend to vary, particularly for short-term horizons. Several months to 10-year time frames may bring discrepancies of dozens of percentage points in the value of the rate $[64,65]$. The discrepancy is explained by the time-delay or framing of the question (gain or loss) [66], but a recent study by Howard, Whitehead, and Hochard [61] comparing various methodologies argue that the discrepancies are in fact lower than what previous studies reported.

In the light of intergenerational perspective two categories of findings matter. The first one is the time-decline of discount rate values, which is depicted by a hyperbolic function [67]. This phenomenon suggests that individuals tend to discount future impact less the further it is in time, and - as the time frame expands intergenerationally - tend to perceive future people's welfare much more equally in comparison with single rate exponential discounting applied in economic appraisal. Second, long-term perspective studies (30 years and more) provide a much more stable range of discount rate values. Depending on the paper, methodology, and the time frame the rates vary between $1 \%$ (for periods 300 years and longer [57]) to $3-4 \%$ (around 100 years or longer $[53,54,56,58]$.

However, the studies devoted in particular to intergenerational issues are rare and they follow wide range of methodologies. The difficulty also arises due to a variety of biases, typical of contingent valuation (e.g., strategic bias, gain-loss valuation discrepancy) [68] followed by hyperbolic discounting anomaly: time-inconsistency of individual decisions (the relation of year-to-year consumption allocation changes as the delay grows) $[30,67]$. While the direct use of IDR in economic appraisal is in general not recommended [59], they may support the intergenerational decisions [51]. Two arguments can be raised to defend the usefulness of the results of those studies. First, since long-term investments, like energy-related programs, impact intergenerationally, they inevitably include a normative aspect of a decision. Second, market-observed choices rarely reach intergenerationally, therefore descriptive methods are of limited usefulness. Designing a hypothetical market with intergenerational intertemporal allocations to elicit IDR may shed some light on both issues: the prescriptive preferences toward future generations of individuals and their intergenerational IDR, unavailable to observe elsewhere. 


\subsection{The Aim of the Paper}

Considering the intergenerational valuation dilemmas, this study aims at answering whether respondents are willing to perceive the benefits accruing to future generations as equally important in comparison with their own gains by eliciting IDR on the basis of surveys among adult representatives of households in Poland. In addition, we intended to answer what drives the willingness to perceive future generations as equally important and whether the drivers differ with the delay and with the benefit type.

The paper adds to the existing literature on intergenerational discounting in several ways. First, it addresses the scarcity of studies devoted to long-term discount rates derived from declared bids of individuals. Second, it adds to the empirical angle of the theory of intergenerational justice by deriving the intergenerational preferences of the people living at present and searching to answer what do we owe to future generations. Third, by referring to saving lives and monetary gains, it addresses the puzzle of discrepancies in the valuation between different types of goods, particularly the issue of private and public impacts, which matter for energy-related investments producing heterogenic outcomes (public-type climate change issues and private-type energy prices). Last but not least, it confronts Poland's single-rate application in economic appraisal, by providing a long-term discount rate value which sheds light on a rationale of switching to time-declining rate regime.

The paper is organized as follows. Section 2 describes the methodology we employed in our research, starting with the questionnaire design and sample description, followed by valuation scenarios and the analytical framework conceptualization with the research questions. Section 3 presents the results of the bids collected, including general descriptive statistics of elicited IDR and models of the relationship between discount rate and delay, socioeconomic and attitude characteristics for various time horizons, and public and private domains. This is followed by the discussion including the implications for energy policy investments. The conclusions section closes the paper.

\section{Materials and Methods}

To elicit IDR a survey was designed as an internet questionnaire and carried out in the Polish language. The invitation to take part in the survey was sent to a nationwide representative sample of individuals (via emails and social networks) using the database of the Centre of Research and Knowledge Transfer at the University of Economics in Katowice. The stratified sampling method was used. The total number of individuals contacted can be estimated roughly from 3500 to 5000 . Filled in questionnaires were returned by 502 respondents out of which 471 were finally used in the analysis (the questionnaires with missing data were excluded; extreme bids were eliminated [69]).

The questionnaire consisted of two parts. The first one contained questions to investigate general attitude to areas related to the well-being of future generations and questions about socioeconomic characteristics. The second one included two valuation scenarios (for lifesaving programs and financial gains) with delayed impacts. The results of the valuation scenarios were used to elicit IDR and then to investigate the values and drivers by setting the models with IDR as a response variable, and the delays, attitude questions as well as socioeconomic characteristics as the explanatory variables.

\subsection{Respondents' Socioeconomic Characteristics and Attitude}

The respondents were asked about their socioeconomic characteristics and attitude to socially important phenomena. A socioeconomic profile was explored by referring to gender, age, education, household income, the size of the household, and whether dependent children were living with the respondent $[51,54,55]$. The gender mix of the sample is similar to Poland's social structure (male: $48 \%$; female: $52 \%$ ), as well as average number of household members (sample-3.02; Poland-2.82), median age (sample-38.7; Poland-37.8). The share of university degree holders and the share of higher-income households were slightly higher than the country average [70]. This may be due to the selection method of respondents (active internet users) which could have influenced the response rate of better 
educated and wealthier respondents. The socioeconomic characteristics of the sample are given in Appendix A.

To design attitude questions a five-point Likert scale was used [71]. The respondents were asked to declare their perceived importance of the well-being of future generations (FGI), environmental protection (EPI), saving human lives (LSI), and the frequency of charity activities (CHF) [61]. The highest importance is given by respondents to saving lives ( 4.5 points on the average). The lowest score was given to charity frequency (mean equal to 2.8), while future generations and environmental protection importance were perceived at a similar level (3.4 and 3.8 respectively).

\subsection{Valuation Scenarios-Transforming Bids into Discount Rates for Lives and Monetary Gains}

In the valuation part, the respondents were given two separate scenarios: referring to lifesaving program (LS) and monetary gains (MG). In each of the above, the respondents were asked to give their bids when choosing between alternative projects. The first project (A) was a lifesaving program for flood control that would save 10 people at present. In the case of the second scenario, monetary gains, the project A was described as winning the money (PLN 100) in the lottery [54]. The second project in the scenarios (B) gives similar type of benefits (respectively: lives saved or monetary gains) but delayed by 10 , 30, 90 or 150 years. The horizons followed the Chapman study in which delays were multiplied by a generation time frame of 30 years [52]. The respondents were then asked to state their project $B$ desired level of benefits for each delay in open-ended questions, the future number of lives saved (or money) that would make them indifferent when choosing between $\mathrm{A}$ and $\mathrm{B}$.

The declared bids making A and B equally desired (therefore assuming that the respondent would stay at the same utility level - the change in utility from accepting project A now is equal to the change in utility from the delayed project $\mathrm{B}: \Delta \mathrm{U}_{\mathrm{A}}=\Delta \mathrm{U}_{\mathrm{B}}$ ) indicate indifference points for intertemporal allocation that allow the calculation of intertemporal discount rates. The bids were transformed assuming continuous compounding $[54,67]$ given by:

$$
D R=\frac{\ln \left(\frac{B}{A}\right)}{n}
$$

where $B$ is the future gains for project $B$; the open-ended question stated value, $A$ is the present gains for project A; 10 lives saved for the LS program or PLN 100 for the MG scenario; and $n$ is the number of years of delay (10; 30; 90 or 150 years).

The respondents answered valuation questions for each delay consecutively, which gave 1884 observations for all delays in total [63]. It was also stated for both projects A (LS and MG) that the contemporary results will be delivered after one year. This was intended to limit the immediacy effect (i.e., Robberstad used delays for immediate benefits between 1 and 4 years [63]) and the variations in time-related uncertainty between present and future effects because immediate delivery of the good could be perceived as certain by respondents, whereas effects delayed in time inevitably suffer from uncertainty.

\subsection{Investigating the IDR Values and Its Drivers-The Conceptual Framework of the Research}

The study aims at answering whether respondents are willing to perceive the benefits accruing to future generations as equally important in comparison with their own gains. It also intends to answer what drives the willingness to perceive future generations as equally important and whether the drivers differ with the delay and with the benefit type.

To address the first research question, the statistical analysis of the elicited IDRs was carried out including basic descriptive statistics (mean, median, mode, dispersion, skewness). The normality of IDR distribution was tested for all effects with KolmogorovSmirnov and W Shapiro-Wilk tests as well as analysis of varinace (ANOVA). Friedman and Wilcoxon signed-rank tests were run at $p$-value of 0.05 to investigate the variations in discount rates between LS and MG for all delays and each delay separately. 
To model what drives the respondent choices stating equal importance of present and future benefits and whether the drivers differ with the delay and the LS vs. MG benefit, IDRs were first divided in two data sets, distinguishing separately positive IDR (lower weight given to the future) and nonpositive IDR (where respondents apply at least equal importance to the future benefit in comparison with present-day gains).

Therefore, the binomial model with logit link function was elaborated with IDR as the explained variable [72]. Accordingly, the elicited IDRs were transformed into binary variable: the model base-state-variable was a positive IDR and the alternative state were nonpositive IDRs (zero and negative values). To analyze the relationship, generalized Linear and nonlinear models in STATISTICA 13 software were used assuming binomial distribution of dependent variable and predictor variables as the combination of quantitative and qualitative drivers (socioeconomic and attitude characteristics) to explain the probability of declaring a positive discount rate. The parameters were estimated based on all effects statistics. The analytical framework with the research questions is presented in Figure 1.

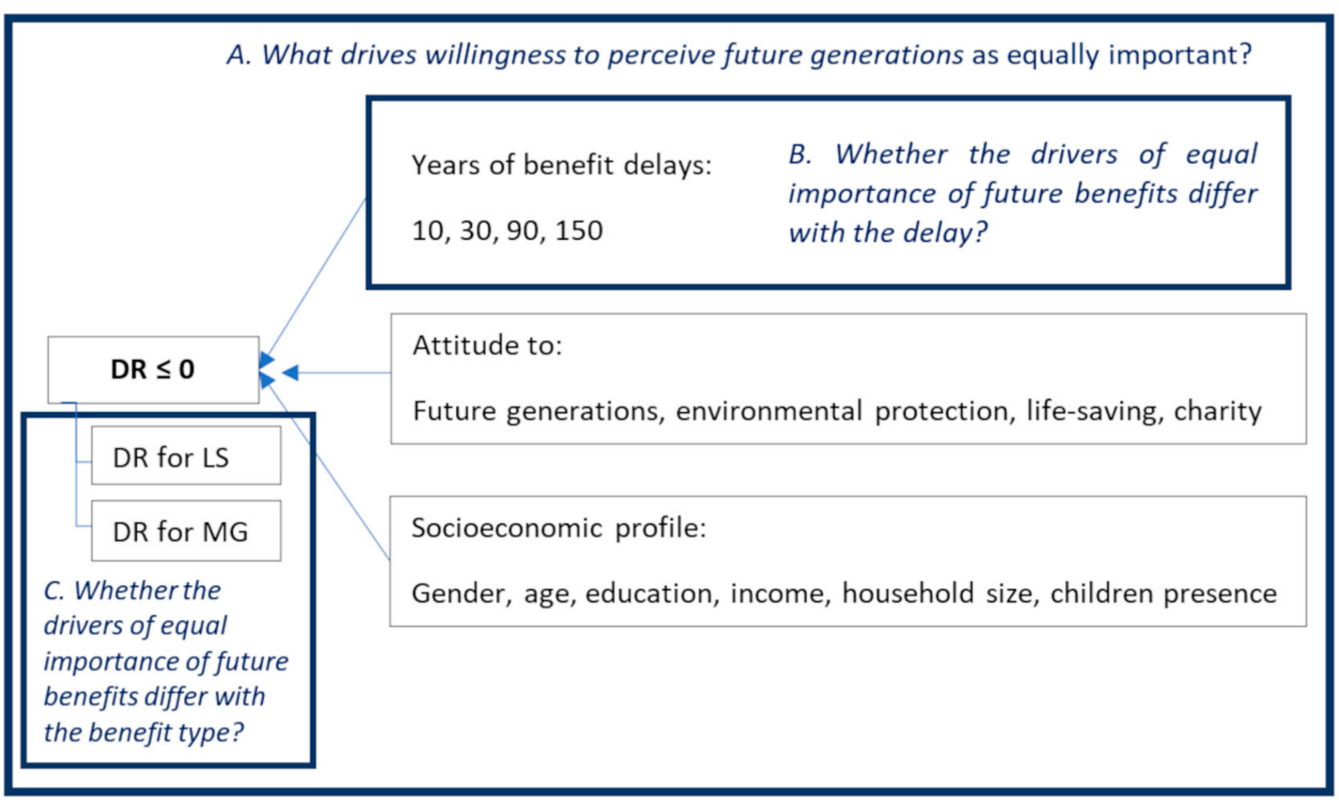

Figure 1. The conceptualization of the research framework.

The predictor variables were delays, socioeconomic characteristics, and attitude. Delays were included in the model as a discrete variable (D-delay): 10, 30, 90 or 150 years. The models were built for LS and MG for all delays and for each delay separately. The socioeconomic profile of respondents was explored by a set of binary variables referring to gender (MALE), age (respondents younger than 45 coded as YNG); education level (respondents not holding university degree coded as NO_UD), average monthly household income per person (LOW_INC for income lower than PLN 2000), household size (S_HH for households with fewer than three members), and presence of dependent children in a family (N_CHILD for households with no dependent children). Attitude characteristics were measured by a fivepoint Likert scale. The importance of well-being of future generations (FGI-future-generation perception), importance of environmental protection (EPI-environmental-protection importance), importance of saving human lives (LSI-lifesaving importance) and the frequency of charity activities ( $\mathrm{CHF}$ - charity frequency) entered the model as continuous variables. The 'fit' of elicited discount rate models was tested using the Bayesian information criteria (BIC) and AIC (Akaike information criterion) [61,73].

\section{Results}

\subsection{An Overview of Individual Discount Rate Values}

The descriptive statistics of individual discount rates are given in Table 1 . The average rates decline with the delay. For lifesaving programs, the 10 -year IDR is close to $14 \%$ and 
then drops with the delay to nearly $3 \%$. In the case of monetary gains, the decrease is higher-short-term mean IDR is $24 \%$, while for the longest delay it is $3.4 \%$.

Table 1. Descriptive statistics for lifesaving program and monetary gains.

\begin{tabular}{|c|c|c|c|c|c|}
\hline \multirow{2}{*}{ Statistics } & \multicolumn{5}{|c|}{ Delay } \\
\hline & 10 & 30 & 90 & 150 & All Delays \\
\hline \multicolumn{6}{|c|}{ Lives saved } \\
\hline$n$ & 468 & 466 & 467 & 467 & 1868 \\
\hline Mean & $13.7 \%$ & $7.5 \%$ & $3.5 \%$ & $2.6 \%$ & $6.8 \%$ \\
\hline Median & $7.7 \%$ & $5.5 \%$ & $2.6 \%$ & $2.0 \%$ & $3.4 \%$ \\
\hline Modal & $0.0 \%$ & $0 \%$ & $0 \%$ & $0 \%$ & $0 \%$ \\
\hline SD & $16.9 \%$ & $7.4 \%$ & $3.3 \%$ & $2.4 \%$ & $10.4 \%$ \\
\hline Skewness & 1.56 & 1.23 & 1.16 & 1.05 & 3.12 \\
\hline \multicolumn{6}{|c|}{ Monetary gains } \\
\hline$n$ & 471 & 471 & 471 & 471 & 1884 \\
\hline Mean & $24.0 \%$ & $11.2 \%$ & $4.9 \%$ & $3.4 \%$ & $10.9 \%$ \\
\hline Median & $25.6 \%$ & $11.7 \%$ & $5.1 \%$ & $3.4 \%$ & $5.7 \%$ \\
\hline Modal & $25.6 \%$ & $11.7 \%$ & $5.1 \%$ & $3.4 \%$ & $0.0 \%$ \\
\hline SD & $17.5 \%$ & $6.9 \%$ & $2.7 \%$ & $2.0 \%$ & $12.5 \%$ \\
\hline Skewness & 0.60 & 0.38 & 0.21 & 0.34 & 2.14 \\
\hline
\end{tabular}

The average rates for LS and MG are higher than median, although the discrepancy is more apparent in the case of lifesaving programs due to the higher skewness of the results (Figure 2). Based on Kolmogorov-Smirnov and W Shapiro-Wilk tests, we rejected the hypothesis that the IDR distribution is normal. ANOVA Friedman test was then backed up by Wilcoxon signed-rank test comparing all delays (10 and 30; 10 and 90; 10 and 150; 30 and 90; 30 and 150; 90 and 150) for LS and MG shows all $p$-values lower than 0.05 indicating that IDRs differ significantly with the delay.

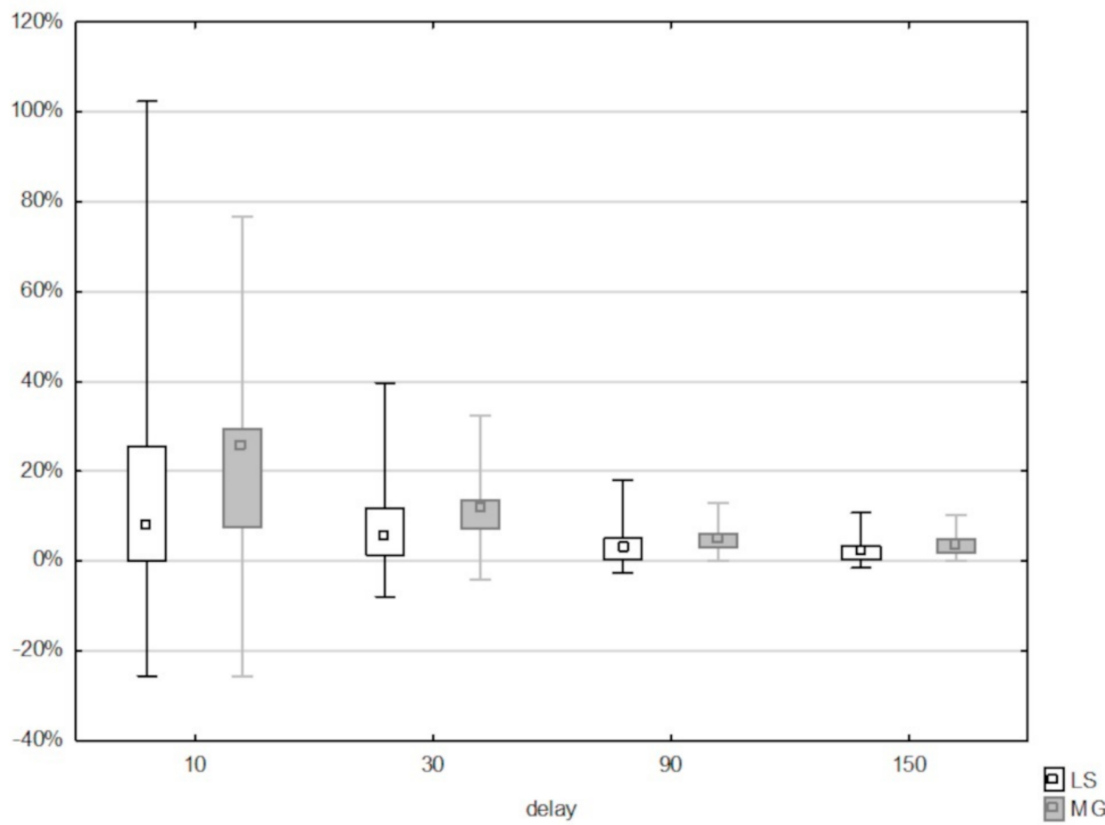

Figure 2. Box (median, Q1-Q3) and whiskers (Min-Max) chart for LS and MG.

Additionally, we tested whether the IDR changes follow hyperbolic decline, which is observed for individual discount rates. We tested several models: power

$$
\mathrm{r}=\mathrm{a} \times \text { delay }^{\mathrm{b}},
$$


Cropper et al. [54]'s rectangular hyperbolic model:

$$
\mathrm{r}=\frac{\mathrm{a}}{\text { delay }}
$$

and Loewenstein and Prelec's model [67]:

$$
\mathrm{r}=\frac{\ln \left((1+\mathrm{a} \times \text { delay })^{\mathrm{b} / \mathrm{a}}\right)}{\text { delay }},
$$

the Loewenstein and Prelec model fits the data best, and the goodness of the fit is higher for MG than for LS. The model for LS is represented by equation:

$$
\mathrm{r}=\frac{\ln \left((1+0.3232 \times \text { delay })^{0.3066 / 0.3232}\right)}{\text { delay }},
$$

with $R^{2}=0.1767$, while MG model is given by:

$$
\mathrm{r}=\frac{\ln \left((1+1.1581 \times \text { delay })^{1.0972 / 1.1581}\right)}{\text { delay }},
$$

with $\mathrm{R}^{2}=0.4194$.

The elicited rates also differ in respect to the domain: both mean and median rates are much higher in the case of the lottery valuation question than in the case of lifesaving scenario. Additionally, the modal DR values for lifesaving projects are zero for each delay investigated. These results were not observed for monetary outcomes. Wilcoxon signedrank test run for differences between LS and MG IDR pairs for each delay $(10,30,90$ and 150 years) returned that all $p$-values are lower than 0.05 . Therefore, IDRs differ significantly between LS and MG.

When concentrating on zero-discount rates, the results also show discrepancies between the type of the benefit (LS or MG) and the length of the time frame. The results show that a considerable share of respondents is willing to treat future generations as equally important in the case of human lives (Table 2). The share is the highest in the case of short delay ( $34 \%$ for 10 years), and then drops to a stable level of about $20 \%$ for the longer delays (30 years and longer). Moreover, the share of respondents declaring equal treatment is more than twofold lower when private financial effects are involved.

Table 2. Share of negative, zero and positive discount rates for lifesaving program and monetary gains.

\begin{tabular}{cccccc}
\hline \multirow{2}{*}{ DR Value } & \multicolumn{5}{c}{ Delay } \\
\cline { 2 - 6 } & $\mathbf{1 0}$ & $\mathbf{3 0}$ & $\mathbf{9 0}$ & $\mathbf{1 5 0}$ & All Delays \\
\hline \multirow{2}{*}{ negative } & $3.8 \%$ & $2.8 \%$ & Lives & \\
zero & $34.0 \%$ & $21.2 \%$ & $21.8 \%$ & $20.8 \%$ & $2.6 \%$ \\
positive & $62.2 \%$ & $76.0 \%$ & $76.0 \%$ & $77.5 \%$ & $72.9 \%$ \\
\hline negative & $0.2 \%$ & $0.8 \%$ & $0.0 \%$ & $0.0 \%$ & $0.3 \%$ \\
zero & $14.2 \%$ & $8.7 \%$ & $9.3 \%$ & $8.9 \%$ & $10.3 \%$ \\
positive & $85.6 \%$ & $90.4 \%$ & $90.7 \%$ & $91.1 \%$ & $89.4 \%$ \\
\hline
\end{tabular}

Negative discount rates (indicating that future gains are more important than contemporary impacts) are observed, but the share is relatively small in the case of LS (3.8\% for 10 years' delay and then drops to less than $2 \%$ for 150 years' delay) and basically negligible for monetary gains (less than $1 \%$ of IDR for 10 and 30 years' delays, not observed for longer time frames). 


\subsection{The Drivers of Individual Discount Rates: The Public-Private Domain and Short and} Long-Term Discrepancies

To investigate the drivers for intertemporal bids, first the models for all delays for lifesaving and monetary gains were built (Table 3 ).

Table 3. Parameter estimates, standard errors (in parentheses) and goodness-of-fit statistics for lifesaving program (LS) and monetary gains (MG) for all delays (binomial model, logit link function, base state of explanatory variable: DR $>0$ ).

\begin{tabular}{|c|c|c|}
\hline Variable & LS & MG \\
\hline Intercept & $\begin{array}{l}-0.04 \\
(0.94)\end{array}$ & $\begin{array}{c}1.12 \\
(0.13) \\
\end{array}$ \\
\hline FGI & $\begin{array}{c}0.06 \\
(0.49)\end{array}$ & $\begin{array}{c}0.09 \\
(0.44)\end{array}$ \\
\hline EPI & $\begin{array}{l}0.16^{* *} \\
(0.02)\end{array}$ & $\begin{array}{c}0.03 \\
(0.79)\end{array}$ \\
\hline LSI & $\begin{array}{c}0.05 \\
(0.53) \\
\end{array}$ & $\begin{array}{l}-0.05 \\
(0.67) \\
\end{array}$ \\
\hline $\mathrm{CHF}$ & $\begin{array}{c}-0.16^{* * *} \\
(0.01)\end{array}$ & $\begin{array}{l}0.15 * \\
(0.10)\end{array}$ \\
\hline $\mathrm{D}$ & $\begin{array}{c}0.00 * * * \\
(0.00)\end{array}$ & $\begin{array}{l}0.00^{* *} \\
(0.02)\end{array}$ \\
\hline MALE & $\begin{array}{c}0.11^{* *} \\
(0.05)\end{array}$ & $\begin{array}{l}-0.04 \\
(0.67)\end{array}$ \\
\hline YNG & $\begin{array}{c}0.15^{* * *} \\
(0.01)\end{array}$ & $\begin{array}{c}0.36^{* * *} \\
(0.00)\end{array}$ \\
\hline NO_UD & $\begin{array}{c}0.06 \\
(0.25)\end{array}$ & $\begin{array}{c}-0.17^{* *} \\
(0.04)\end{array}$ \\
\hline LOW_INC & $\begin{array}{c}0.25 * * * \\
(0.00)\end{array}$ & $\begin{array}{c}-0.21^{* *} \\
(0.01)\end{array}$ \\
\hline S_HH & $\begin{array}{c}-0.23^{* * *} \\
(0.00)\end{array}$ & $\begin{array}{c}-0.57^{* * *} \\
(0.00)\end{array}$ \\
\hline N_CHILD & $\begin{array}{c}0.20^{* * *} \\
(0.00)\end{array}$ & $\begin{array}{l}0.19 * \\
(0.05)\end{array}$ \\
\hline Scale & $\begin{array}{c}1 \\
(0.00)\end{array}$ & $\begin{array}{c}1 \\
(0.00)\end{array}$ \\
\hline $\begin{array}{l}\text { AIC } \\
\text { BIC }\end{array}$ & $\begin{array}{l}2117.16 \\
2183.53\end{array}$ & $\begin{array}{l}1215.15 \\
1281.62\end{array}$ \\
\hline
\end{tabular}

The analysis of statistically significant variables indicates some discrepancies between the models. The delay variable is highly significant for both models, but the socioeconomic and attitude characteristics differ between lifesaving and monetary benefits. Higher probability of declaring positive discount rate for lifesaving was found for younger, less wealthy male respondents, without children and with larger households. Positive rates were stated with higher probability by respondents declaring higher importance of environmental protection and those who indicated lower frequency of charitable donations. On the other hand, considering financial gains: younger age and lack of children increase the probability of declaring positive DR, while lower education level, lower income, and more members of household decrease it. The income and donation frequency, while significant for both models, influence the probability of declaring a positive rate in opposite directions for MG and LS. The drivers that differ between the models are gender, education, and environmental importance. 
Tables 4 and 5 present the results for model parameters for lifesaving program and monetary gains developed for each delay separately.

Referring to separate-delay-models for lifesaving programs (Table 4), some differences within the IDR drives can be observed, depending on the time frame. Variables: charity donations, gender, and age matter only for 10 years' delay (male and younger respondents tend to discount more intensively, higher charity frequency is conducive to non-positive $\mathrm{DR})$. On the contrary, the size of the household matters for explaining DR in the case of 30 years' delay and longer. Larger families tend to apply positive DR to those horizons. The presence of dependent children matters for horizons up to 30 years and tends to lower the probability of declaring positive DR. Finally, the income enters the models inconclusively, but since $p$-value for 10 and 30 years' delays was below 0.01 , while for 90 years' delay was 0.17 and for 150-year delay was slightly above 0.06 , we could interpret this driver in terms of diminishing importance with time.

Table 4. Parameter estimates, standard errors (in parentheses) and goodness-of-fit statistics for lifesaving program for delays separately (binomial model, logit link function, base state of explanatory variable: DR $>0$ ).

\begin{tabular}{|c|c|c|c|c|}
\hline Variable & LS10 & LS30 & LS90 & LS150 \\
\hline Intercept & $\begin{array}{l}-0.78 \\
(0.39)\end{array}$ & $\begin{array}{c}0.50 \\
(0.63)\end{array}$ & $\begin{array}{c}0.59 \\
(0.58)\end{array}$ & $\begin{array}{c}0.93 \\
(0.38)\end{array}$ \\
\hline FGI & $\begin{array}{c}0.1 \\
(0.50)\end{array}$ & $\begin{array}{c}0.02 \\
(0.90)\end{array}$ & $\begin{array}{c}0.05 \\
(0.76)\end{array}$ & $\begin{array}{c}0.05 \\
(0.75)\end{array}$ \\
\hline EPI & $\begin{array}{c}0.13 \\
(0.32)\end{array}$ & $\begin{array}{c}0.12 \\
(0.42)\end{array}$ & $\begin{array}{c}0.20 \\
(0.18)\end{array}$ & $\begin{array}{c}0.22 \\
(0.13)\end{array}$ \\
\hline LSI & $\begin{array}{c}0.22 \\
(0.17)\end{array}$ & $\begin{array}{c}0.07 \\
(0.68)\end{array}$ & $\begin{array}{c}0.01 \\
(0.98)\end{array}$ & $\begin{array}{l}-0.12 \\
(0.51)\end{array}$ \\
\hline $\mathrm{CHF}$ & $\begin{array}{c}-0.25^{* *} \\
(0.03)\end{array}$ & $\begin{array}{l}-0.11 \\
(0.38)\end{array}$ & $\begin{array}{l}-0.18 \\
(0.16)\end{array}$ & $\begin{array}{l}-0.12 \\
(0.37)\end{array}$ \\
\hline MALE & $\begin{array}{l}0.18 * \\
(0.08)\end{array}$ & $\begin{array}{c}0.13 \\
(0.26)\end{array}$ & $\begin{array}{c}0.05 \\
(0.64)\end{array}$ & $\begin{array}{c}0.07 \\
(0.53)\end{array}$ \\
\hline YNG & $\begin{array}{c}0.25^{* *} \\
(0.02)\end{array}$ & $\begin{array}{c}0.08 \\
(0.50)\end{array}$ & $\begin{array}{c}0.1 \\
(0.41)\end{array}$ & $\begin{array}{c}0.18 \\
(0.12)\end{array}$ \\
\hline NO_UD & $\begin{array}{c}0.02 \\
(0.84)\end{array}$ & $\begin{array}{c}0.01 \\
(0.92)\end{array}$ & $\begin{array}{c}0.14 \\
(0.23)\end{array}$ & $\begin{array}{c}0.09 \\
(0.44)\end{array}$ \\
\hline LOW_INC & $\begin{array}{c}0.30^{* * * *} \\
(0.01)\end{array}$ & $\begin{array}{c}0.33^{* * *} \\
(0.01)\end{array}$ & $\begin{array}{c}0.16 \\
(0.17)\end{array}$ & $\begin{array}{l}0.23 * \\
(0.05)\end{array}$ \\
\hline S_HH & $\begin{array}{l}-0.18 \\
(0.13)\end{array}$ & $\begin{array}{c}-0.24 \text { * } \\
(0.07)\end{array}$ & $\begin{array}{c}-0.29^{* *} \\
(0.03)\end{array}$ & $\begin{array}{c}-0.23 \text { * } \\
(0.09)\end{array}$ \\
\hline N_CHILD & $\begin{array}{c}0.27 * * \\
(0.02)\end{array}$ & $\begin{array}{l}0.23 * \\
(0.09)\end{array}$ & $\begin{array}{c}0.16 \\
(0.26)\end{array}$ & $\begin{array}{c}0.14 \\
(0.31)\end{array}$ \\
\hline Scale & $\begin{array}{c}1 \\
(0.00)\end{array}$ & $\begin{array}{c}1 \\
(0.00) \\
\end{array}$ & $\begin{array}{c}1 \\
(0.00)\end{array}$ & $\begin{array}{c}1 \\
(0.00) \\
\end{array}$ \\
\hline $\begin{array}{l}\mathrm{AIC} \\
\mathrm{BIC}\end{array}$ & $\begin{array}{l}614.96 \\
660.57\end{array}$ & $\begin{array}{l}516.78 \\
562.34\end{array}$ & $\begin{array}{l}517.71 \\
563.30\end{array}$ & $\begin{array}{l}504.25 \\
549.84\end{array}$ \\
\hline
\end{tabular}


Table 5. Parameter estimates, standard errors (in parentheses) and goodness-of-fit statistics for monetary gains for delays separately (binomial model, logit link function, base state of explanatory variable: DR $>0$ ).

\begin{tabular}{|c|c|c|c|c|}
\hline Variable & MG10 & MG30 & MG90 & MG150 \\
\hline Intercept & $\begin{array}{l}-0.48 \\
(0.69)\end{array}$ & $\begin{array}{l}2.73 * \\
(0.09)\end{array}$ & $\begin{array}{c}2.43 \\
(0.14)\end{array}$ & $\begin{array}{c}1.46 \\
(0.35)\end{array}$ \\
\hline FGI & $\begin{array}{c}0.12 \\
(0.57)\end{array}$ & $\begin{array}{l}-0.39 \\
(0.87)\end{array}$ & $\begin{array}{c}0.19 \\
(0.43)\end{array}$ & $\begin{array}{c}0.13 \\
(0.62)\end{array}$ \\
\hline EPI & $\begin{array}{c}0.00 \\
(0.99)\end{array}$ & $\begin{array}{c}0.04 \\
(0.85)\end{array}$ & $\begin{array}{c}0.04 \\
(0.85)\end{array}$ & $\begin{array}{c}0.02 \\
(0.94)\end{array}$ \\
\hline LSI & $\begin{array}{c}0.28 \\
(0.17)\end{array}$ & $\begin{array}{l}-0.32 \\
(0.26)\end{array}$ & $\begin{array}{l}-0.33 \\
(0.25)\end{array}$ & $\begin{array}{l}-0.03 \\
(0.90)\end{array}$ \\
\hline $\mathrm{CHF}$ & $\begin{array}{c}0.17 \\
(0.30)\end{array}$ & $\begin{array}{c}0.23 \\
(0.24)\end{array}$ & $\begin{array}{c}0.09 \\
(0.64)\end{array}$ & $\begin{array}{c}0.15 \\
(0.46)\end{array}$ \\
\hline MALE & $\begin{array}{c}0.04 \\
(0.77)\end{array}$ & $\begin{array}{l}-0.12 \\
(0.49)\end{array}$ & $\begin{array}{l}-0.07 \\
(0.68)\end{array}$ & $\begin{array}{c}0.01 \\
(0.97)\end{array}$ \\
\hline YNG & $\begin{array}{l}0.23 * \\
(0.10)\end{array}$ & $\begin{array}{c}0.49 * * * \\
(0.00)\end{array}$ & $\begin{array}{l}0.43^{* *} \\
(0.01)\end{array}$ & $\begin{array}{c}0.34 \text { ** } \\
(0.05)\end{array}$ \\
\hline NO_UD & $\begin{array}{c}-0.26 * \\
(0.08)\end{array}$ & $\begin{array}{l}-0.05 \\
(0.76)\end{array}$ & $\begin{array}{l}-0.11 \\
(0.51)\end{array}$ & $\begin{array}{l}-0.23 \\
(0.20)\end{array}$ \\
\hline LOW_INC & $\begin{array}{l}-0.19 \\
(0.19)\end{array}$ & $\begin{array}{l}-0.21 \\
(0.25)\end{array}$ & $\begin{array}{l}-0.21 \\
(0.24)\end{array}$ & $\begin{array}{l}-0.22 \\
(0.23)\end{array}$ \\
\hline S_HH & $\begin{array}{c}-0.41^{* * *} \\
(0.01)\end{array}$ & $\begin{array}{c}-0.65^{* * *} \\
(0.00)\end{array}$ & $\begin{array}{c}-0.68^{* * *} \\
(0.00)\end{array}$ & $\begin{array}{c}-0.63^{* * *} \\
(0.00)\end{array}$ \\
\hline N_CHILD & $\begin{array}{c}0.19 \\
(0.24)\end{array}$ & $\begin{array}{c}0.26 \\
(0.21)\end{array}$ & $\begin{array}{c}0.26 \\
(0.23)\end{array}$ & $\begin{array}{c}0.01 \\
(0.97)\end{array}$ \\
\hline Scale & $\begin{array}{c}1 \\
(0.00)\end{array}$ & $\begin{array}{c}1 \\
(0.00)\end{array}$ & $\begin{array}{c}1 \\
(0.00)\end{array}$ & $\begin{array}{c}1 \\
(0.00)\end{array}$ \\
\hline $\begin{array}{l}\text { AIC } \\
\text { BIC }\end{array}$ & $\begin{array}{l}392.29 \\
437.97\end{array}$ & $\begin{array}{l}249.13 \\
339.81\end{array}$ & $\begin{array}{l}291.04 \\
336.72\end{array}$ & $\begin{array}{l}285.02 \\
330.70\end{array}$ \\
\hline
\end{tabular}

In the case of monetary gains, the delay-dependent variability of the drivers is lower (Table 5). The variables that are significant for all delays analyzed are: the age (younger respondents are more likely to apply a positive discount rate) and the size of the household (smaller families tend to declare a nonpositive discount rate more often). The level of education alone distinguishes 10 years' delay from longer time frames, and it is negatively correlated with the probability to declare a positive discount rate.

\section{Discussion}

The results reported in this study form a basis to pay more attention to future generations than via the currently applied single-rate exponential discounting regime in Poland, which is depicted here by time-declining IDRs. The perceived importance that future generations are accounted for by those living at present also depends strongly on the type of benefit the investment is about to bring. Several research results support this claim and they will be discussed in this section along with the comparison with other studies followed by the limitations of the findings.

First, the hyperbolic decline in discount rates observed for both types of benefits analyzed in this study: human lives and lottery gains, suggest that the further in time the outcome is, the more preferential treatment it gets (due to a lower discount rate). The mean LS rates decrease with time from $13.7 \%$ for intragenerational intertemporal allocations (10 years) to $2.6 \%$ for the fifth generation time span (150 years), while MG rates decrease from $24 \%$ to $3.4 \%$ respectively. It is worth highlighting that the assumption of hyperbolic decline must be interpreted carefully since the models' parameters were estimated based on four delays only (10, 30, 90 and 150 years) which resulted in relatively low R-squared values and small variations between $\mathrm{R}^{2}$ for different models. The survey with higher number of time horizons could produce results better suited to hyperbolic function. 
Regarding IDR values, other studies report similar range for long-term perspective, but short-term observations give varied results. While Egan, Corrigan, and Dwyer [65], in a lottery with 10 years' delay, report median rates in the range $17-20 \%$, similar to our findings, some papers find much higher rates (e.g., $50 \%$ or even higher than $100 \%[55,64,74]$ ), or similar ones for shorter periods (e.g., the average rate in this study for all delays is $6.8 \%$ and $10.9 \%$ respectively, while Howard's [60] estimate of the average rate is $11.6 \%$ for 14 weeks' delay). Although the results differ, depending on the framing of the question and the time frame [66], the study by Howard, Whitehead, and Hochard testing various methodologies finds a consistent range of estimates between $14.5 \%$ and $31 \%$ for delays up to 10 years [61]. Our short-term results fell closely into this range.

The number of studies applying intergenerational time frames to elicit individual discount rates is not large, but, in general, they find values close to our results. Cropper et al. indicate the drop from nearly $17 \%$ for 5 years' delay to $3.4 \%$ for 100 years [54], comparable with Frederick's results of 3.8\% for the same time horizon [53]. Meerding et al. give slightly lower estimate-slightly higher than 1\% (40-year horizon) [59]. Our estimates to some extent follow experts' direct bids of a long-term (more than 100 years) discount rate by Drupp et al., where the median discount rate was found to be equal to $2 \%$ [58]. Weitzman's paper investigating economists' 'professionally considered gut feeling' for the discount rate of climate change projects gives an estimate in the range of 3-4\% [56].

The studies also report the time-decline in rates following hyperbolic function, which is similar to the results reported here. However, the decrease in the IDR values should not be explained only in terms of the increasing importance given to future generations by individuals living at present since hyperbolic discounting phenomenon is observed also for a short time [75], as well as the physical distance [76].

While considering the inevitable limitations of such comparisons, due to countryspecifics and methodological design discrepancies [66], the values in the study generally follow the patterns identified elsewhere, particularly for longer delays as the variability of the rates decreases in multigenerational time frame, leading to estimates in a reasonably stable range of $2-4 \%$.

Second, a considerable portion of respondents is willing to declare equal importance between present and future outcomes, particularly in the case of lifesaving programs-for delays of 30 years and longer our results show a stable share of one fifth of respondents willing to treat future generations' benefits equally in comparison with their own gains. Chapman and Frederick's results $[52,66]$ also indicate equal treatment of benefits accruing for the present generations and those for the future generation. However, Frederick found the results sensitive to question format. Additionally, the share of zero discount rate responses for lives saved followed Chapman's results, reporting 26-28\% share of zero IDR. Frederick found an even higher proportion in this case, reaching $43 \%$ of respondents who declared the same number of people saved now and in the future. This could be further supported by Luckert and Adamowicz, who also find that over half of respondents choose zero discount rates [51]. Breuer, Müller, and Sachsenhausen also found willingness to declare nonpositive discount rate in the intergenerational setting, but their results differ depending on the setting involved [77].

Third, what should be highlighted in the light of energy-related projects generating mainly public-type benefits in the long term (e.g., RES investments to mitigate climate change and environmental burden) is the discrepancy in discounting between lifesaving and money shedding the light on individual preferences over public vs. private spheres. The results over the spheres differ in respect to the IDR values, share of nonpositive IDRs and the set of explanatory variables.

The IDR values are higher by about $50 \%$ for money while the share of zero IDR is less by $50 \%$ of what can be observed for lifesaving programs for all delays investigated. The money discounting also differs in terms of the distribution as the results are positively skewed in this case. Interpreting a lifesaving program as a public domain and a lottery gain as a private one, our results stay in line with numerous studies. Monetary gains are 
found to be discounted stronger, e.g., by $[54,59,78]$. Luckert, and Adamowicz found that a privately-managed good is given higher rates than a similar good, but publicly managed, and, irrespectively to the above, an environmental good (forest) is discounted less than financial assets (a portfolio of bonds and stocks) [51]. Howard found the discrepancy in rates between private and social domain reaching $12.3-17.6 \%$ points [60] (in this study: $11-20 \%$ points, depending on the delay). Breuer, Müller, and Sachsenhausen also found stronger willingness to discount private gains transferred intergenerationally in comparison with social sphere (intertemporal benefits for others) [77]. However, those findings are not supported by Chapman, who found no difference between type of goods (lives, health, and financial benefits). She also noticed that her results show lower discrepancies in comparison with other studies [52].

Not only does the value depend on the type of the benefit that is provided in the future, but also the drivers of discount rate. Gender and education characteristics as well as the attitude to protecting the environment differentiate the variable-set between LS and MG models built for all delays, while the charity donations and income level, although found to be significant in both cases, influence the probability of declaring nonpositive DR in the opposite direction. The results of the study suggest distinguishing not only between private and public impacts, but also between the short, intragenerational frame the and long, intergenerational one. The drivers of declaring equal (or higher) importance of the future lives saved that were found significant in this study are gender, age, income, household size and child presence but they differ, depending on whether a short term (10 years) is considered or a long perspective (30 years or more) indicating that the future generations are given a separate stance. What should be highlighted is that when analyzing the drivers of the discount rate in the long-run (30-year delay and higher) we also observed that in the case of preferences over monetary gains, those drivers seem to be much less sensitive to changing the decision frame from intra- to intergenerational.

Cropper et al. found the discrepancies in factors influencing lifesaving programs for short term (5-10 years) and long-term (25-100 years), observing an opposite direction of influence in the case of gender, education, or marital status [54]. Moreover, Meerding et al. [56] observe some divergence in variables for money in comparison with health. Luckert, and Adamowicz as well as Berry et al. also explain disparities in public vs. private discount rates by varying personal characteristics set [51,78], while Breuer et al. found that a long-term and prosocial orientation drives intergenerational preferences [77].

Although the disparity in the set of drivers is confirmed by other authors, some variables influence varies in comparison with this study's results, which limits the usefulness of the interpretation. Higher rates for better educated and lower for lower income respondents for money in this study are supported by [51,59], but, in the case of lifesaving programs, education was found to be insignificant along with lower income which increases the probability of applying a positive IDR. Cropper et al. found higher rates for respondents with young children and females [54], while this study shows the opposite.

The discrepancy in discounting between monetary gains and lives saved is given multiple explanations. Breuer et al. relate it to the effect of self-control problems due to personal immediate rewards for the individuals living at present [77]. Moser et al. point that when an individual is more emotionally involved about the future outcome, they tend to discount less [79]. The emotions raised by lifesaving program are higher than in the case of the lottery, which is reflected by lower IDR. The explanation can also be given by the fact that the welfare of future generations possess pure public good characteristics: nonrivalry and nonexcludability, which creates for individuals living now the incentives to become free-riders [51]. Finally, some evidence is given by the duality of roles played by individuals when facing the private-public goods puzzle: the choice we make as a consumer in a private domain may differ from our choices as a citizen, whereas in a public sphere, future generations' welfare comes into play [80,81], e.g., Mill et al. indicate that respondents who take a citizen's perspective tend to put similar values on various types of forests, while as consumers their valuations differ [82]. 


\section{Conclusions}

The question of whether future generations can be given an equal stance with people living at present is of great importance for energy-related investments. The paper aimed at shedding some light on this issue and the results support more equal treatment of future generations than what emerges from current economic appraisal practice.

Energy related issues are of major concern for policy-makers these days due to their importance for the well-being of the present and future generations. The restricted public financial resources, particularly nowadays, due to COVID-19 economic recession, challenge the task of effective allocation of limited resources to achieve maximum welfare increase. The wise evaluation process is essential in this case as it helps to choose best investment proposals. Economic evaluation rests on comparing present-day outlays with future gains and the discount rate makes those comparisons feasible. However, the higher discount rate is, and the longer investment project lasts, the future impacts value less at present. This is particularly important for energy-related investments, as many of them, e.g., renewable sources replacing fossil fuels to combat the climate warming, dams and hydroelectric power plants infrastructure, nuclear power plants and radioactive wastes management projects, face very long, intergenerational, life cycle. The choice of the discount rate is decisive here for acceptance or rejection and when biased, it negatively influences the society well-being, because the funds could be spent elsewhere more effectively. The paper's results aim to limit the risk of such inefficiency: they form the rationale of switching to declining discount rate regime for intergenerational energy investments, giving higher weight to far-future impacts that are compared with undiscounted present-day outlays. Additionally, the results support the claim of separate evaluation between private- and public-type benefits as the latter is described by lower discount rates and higher future impacts weight, which could potentially increase the willingness of public authorities to incentivize more energy-related investments benefiting the society (both in the long and short term), and less concentrated on maximizing private corporate profits.

As some researchers [59] point out that policy-makers should be careful with direct application of IDR as a social discount rate for investment evaluation, we also observed individuals' heterogeneous motives over preferring present to future consumption. Therefore, we argue that the results should not be used in respect to the application of pure IDR values, but rather as a basis to give the rationale for switching from a single-rate to a declining discount rate profile for Poland, following countries like France or the United Kingdom. The observed time-decline of IDR accompanied by high share of zero discount rates along with a consistency of long-term IDR values with other intergenerational rates estimates, both implicit as well as directly declared, support this claim.

The observed discrepancies between monetary gains and saving lives, both in values as well as the drivers, provide a rationale that future generations could be perceived as a public good and deserve a separate treatment, particularly for the decisions that could influence the basic needs (e.g., increased mortality risk due to climate warming). At the same time providing future people with private goods (which could be related to future electricity prices) is raising much less willingness to invest (higher discount rates for monetary gains). Luckert and Adamowicz, analyzing the discrepancy between privately and publicly-managed goods, argue that even if the results may not be sufficient to alter public policy, a considerable attention should be given to this area. They highlight that future generations' welfare, having public good characteristics, is underprovided by markets and increased public regulation may reduce the level of inefficiencies, increasing the social welfare [51].

The results could also be useful to decision-makers by providing the insight into society's willingness to invest on behalf of future generations depending on the way the outcomes of actions aiming at the future are described and what personal characteristics determine the eagerness to intertemporally allocate the consumption. Such insight can add to various areas in energy policy planning, starting from climate change mitigation, and ending with radioactive waste management. The findings of the paper also may support alternative funding schemes for renewable energy - the knowledge of long-term 
preferences and how they influence the present-day value of delayed effect could matter for crowdfunding models of RES financing, e.g., a philanthropic-crowdfunding-partnership model gaining attention in case of solar farms [83] as a way to switch to clean-energy sources faster. The paper adds to the Polish perspective further, since the Polish nuclear program is still at its infancy, and climate-neutrality demands high investment outlays, the development of a time scheme of our responsibilities toward future generations could be helpful in answering whether and how fast future outcomes should decline in time.

Funding: This research received no external funding.

Institutional Review Board Statement: Ethical review and approval were waived for this study, due to the fact that the survey contained questions focusing on policies and investments, did not collect any private, identifiable information about respondents, all responses were anonymous, and the participation was voluntary.

Informed Consent Statement: Participants' consent was waived due to the fact that the survey contained questions focusing on policies and investments, did not collect any private, identifiable information about respondents, all responses were anonymous, and the participation was voluntary.

Data Availability Statement: The data presented in this study are available on request from the corresponding author. The data are not publicly available due to privacy restrictions.

Conflicts of Interest: The author declare no conflict of interest.

\section{Appendix A}

Table A1. Socioeconomic characteristics of the sample.

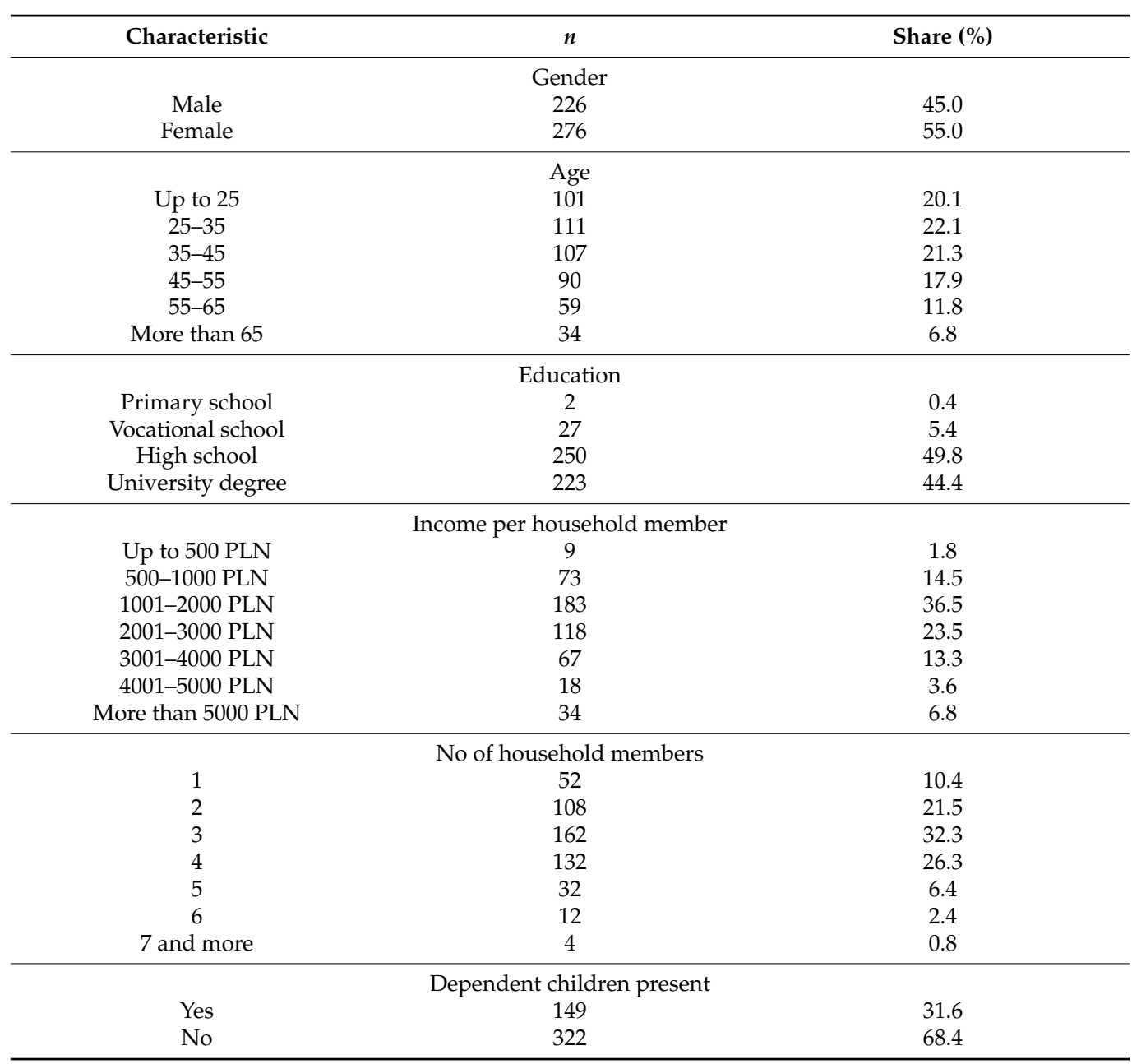




\section{References}

1. Ramsey, F.P. A Mathematical Theory of Saving. Econ. J. 1928, 38, 543-559. [CrossRef]

2. Guide to Cost-Benefit Analysis of Investment Projects. Economic Appraisal Tool for Cohesion Policy 2014-2020; European Commission: Brussels, Belgium, 2015.

3. Maselli, G.; Nesticò, A. The Role of Discounting in Energy Policy Investments. Energies 2021, 14, 6055. [CrossRef]

4. Eurostat. Available online: https:/ / ec.europa.eu/ eurostat (accessed on 2 November 2021).

5. Global Carbon Atlas. Available online: http://www.globalcarbonatlas.org/en/content/welcome-carbon-atlas (accessed on 8 December 2020).

6. Polityka Energetyczna Polski Do Roku 2040; Ministry of Climate and Environment: Warsaw, Poland, 2021.

7. Regulation (EU) 2021/1119 of the European Parliament and of the Council of 30 June 2021 Establishing the Framework for Achieving Climate Neutrality and Amending Regulations (EC) No 401/2009 and (EU) 2018/1999 ('European Climate Law'). Available online: https:/ / eur-lex.europa.eu/eli/reg/2021/1119/oj (accessed on 1 December 2021).

8. Wkład Polskiego Sektora Energetycznego w Realizacje Globalnej Polityki Klimatycznej; Polish Electricity Association: Warsaw, Poland, 2018.

9. Program Polskiej Energetyki Jądrowej. Available online: https://www.gov.pl/web/polski-atom/program-polskiej-energetykijadrowej-2020-r (accessed on 2 November 2021).

10. Sosiński, D. Zarządzanie Ryzykiem w Projektach Inwestycyjnych Zorientowanych Na Wytwarzanie Energii Odnawialnej. In Ryzyko Inwestowania w Polskim Sektorze Energetyki Odnawialnej; Kasiewicz, S., Ed.; CeDeWu: Warszawa, Poland, 2012.

11. Blanco, M.I. The Economics of Wind Energy. Renew. Sustain. Energy Rev. 2009, 13, 1372-1382. [CrossRef]

12. Raugei, M.; Fullana-i-Palmer, P.; Fthenakis, V. The Energy Return on Energy Investment (EROI) of Photovoltaics: Methodology and Comparisons with Fossil Fuel Life Cycles. Energy Policy 2012, 45, 576-582. [CrossRef]

13. Rogowski, W.; Rak, P. Zarządzanie Ryzykiem w Projektach Budowy i Eksploatacji Hydroelektrowni. In Ryzyko Inwestowania W Polskim Sektorze Energetyki Odnawialnej; Kasiewicz, S., Ed.; CeDeWu: Warszawa, Poland, 2012.

14. Atlason, R.S.; Unnthorsson, R. Energy Return on Investment of Hydroelectric Power Generation Calculated Using a Standardised Methodology. Renew. Energy 2014, 66, 364-370. [CrossRef]

15. Stern, N. The Economics of Climate Change: The Stern Review; Cambridge University Press: Cambridge, UK, 2007; ISBN 978-0-521-70080-1.

16. Tol, R.S.J. Equitable Cost-Benefit Analysis of Climate Change Policies. Ecol. Econ. 2001, 36, 71-85. [CrossRef]

17. Groom, B.; Hepburn, C.; Koundouri, P.; Smale, R.; Pearce, D. A Social Time Preference Rate for Use in Long-Term Discounting. Available online: https://www.oxera.com/insights/reports/a-social-time-preference-for-use-in-long-term-discounting/ (accessed on 2 November 2021).

18. Newell, R.; Pizer, W. Discounting the Benefits of Future Climate Change Mitigation; Center on Global Climate Change: Washington, DC, USA, 2001.

19. Moore, M.A.; Boardman, A.E.; Vining, A.R.; Weimer, D.L.; Greenberg, D.H. “Just Give Me a Number!" Practical Values for the Social Discount Rate. J. Policy Anal. Manag. 2004, 23, 789-812. [CrossRef]

20. Anthoff, D.; Tol, R.S.J.; Yohe, G.W. Discounting for Climate Change. Economics 2009, 3, 20090024. [CrossRef]

21. Jansen, J.; Bakker, S. Social Cost-Benefit Analysis of Climate Change Mitigation Options in a European Context; ECN-E-06-059; Energy research Centre of the Netherlands ECN: The Hague, The Netherlands, 2006.

22. Ilg, P.; Gabbert, S.; Weikard, H. Nuclear Waste Management under Approaching Disaster: A Comparison of Decommissioning Strategies for the German Repository Asse II. Risk Anal. 2017, 37, 1213-1232. [CrossRef]

23. Page, E.A. Climate Change, Justice and Future Generations; Edward Elgar Publishing: Cheltenham, UK, 2006; ISBN 978-1-84542-471-8.

24. Markandya, A. Equity and Distributional Implications of Climate Change. World Dev. 2011, 39, 1051-1060. [CrossRef]

25. Taebi, B. Intergenerational Risks of Nuclear Energy. In Handbook of Risk Theory Epistemology, Decision Theory, Ethics, and Social Implications of Risk; Roeser, S., Hillerbrand, R., Sandin, P., Peterson, M., Eds.; Springer: Dordrecht, The Netherlands; Heidelberg, Germany; London, UK; New York, NY, USA, 2012; pp. 295-318.

26. Principles of Radioactive Waste Management Safety Fundamentals; Safety Series; International Atomic Energy Agency: Vienna, Austria, 1995; ISBN 92-0-103595-0.

27. Gardiner, S.M. A Perfect Moral Storm: Climate Change, Intergenerational Ethics and the Problem of Moral Corruption. Environ. Values 2006, 15, 397-413. [CrossRef]

28. Caney, S. Climate Change, Intergenerational Equity and the Social Discount Rate. Politics Philos. Econ. 2014, 13, 320-342. [CrossRef]

29. Foltyn-Zarychta, M. Ocena Inwestycji Międzypokoleniowych-Kryteria Etyczne w Ekonomicznej Ocenie Efektywności Projektów Inwestycyjnych; C.H. Beck: Warszawa, Poland, 2018.

30. Arrow, K.J.; Cropper, M.L.; Gollier, C.; Groom, B.; Heal, G.M.; Newell, R.G.; Nordhaus, W.D.; Pindyck, R.S.; Pizer, W.A.; Portney, P.R.; et al. Should Governments Use a Declining Discount Rate in Project Analysis? Rev. Environ. Econ. Policy 2014, 8, 145-163. [CrossRef]

31. The Green Book Central Government Guidance on Appraisal and Evaluation 2020; HM Treasury: London, UK, 2020.

32. Economic Appraisal Vademecum 2021-2027-General Principles and Sector Applications; European Commission: Brussels, Belgium, 2021.

33. Evans, D.J.; Sezer, H. Social Discount Rates for Member Countries of the European Union. J. Econ. Stud. 2005, 32, 47-59. [CrossRef]

34. Florio, M.; Sirtori, E. The Social Cost of Capital: Recent Estimates for the EU Countries; CSIL Centre for Industrial Studies: Milano, Italy, 2013.

35. Seçilmiş, E.; Akbulut, H. Social Discount Rates for Six Transition Countries. Ekon. Čas. 2019, 67, 629-646.

36. Foltyn-Zarychta, M.; Buła, R.; Pera, K. Discounting for Energy Transition Policies-Estimation of the Social Discount Rate for Poland. Energies 2021, 14, 741. [CrossRef]

37. Ustawa z Dnia 11 Stycznia 2018 r. o Elektromobilności i Paliwach Alternatywnych. Available online: https://isap.sejm.gov.pl/ isap.nsf/DocDetails.xsp?id=WDU20180000317 (accessed on 5 November 2021). 
38. Foltyn-Zarychta, M.; Marcinek, K.; Tomecki, M. Metodyczne Dylematy Oceny Inwestowania w Elektromobilność 2021. In Modern Challenges for Real Estate Manadement. The Conference, 20-21 September 2021, Kraków, Poland; Cracow University of Economics: Kraków, Poland, 2021.

39. Przegląd Przepisów na Potrzeby Etapu 4. (2021-2030). Available online: https:/ / ec.europa.eu/clima/eu-action/eu-emissionstrading-system-eu-ets/revision-phase-4-2021-2030_pl (accessed on 2 November 2021).

40. Lemken, D.; Zühlsdorf, A.; Spiller, A. Improving Consumers' Understanding and Use of Carbon Footprint Labels on Food: Proposal for a Climate Score Label. EuroChoices 2021, 20, 23-29. [CrossRef]

41. Weitzman, M.L. Why the Far-Distant Future Should Be Discounted at Its Lowest Possible Rate. J. Environ. Econ. Manag. 1998, 36, 201-208. [CrossRef]

42. Gollier, C. Time Horizon and the Discount Rate. J. Econ. Theory 2002, 107, 463-473. [CrossRef]

43. Lucas, R.E., Jr. Asset Prices in an Exchange Economy. Econom. J. Econom. Soc. 1978, 46, 1429-1445. [CrossRef]

44. Gollier, C. Evaluation of Long-Dated Investments under Uncertain Growth Trend, Volatility and Catastrophes. CESIFO Working Paper No. 4052. December 2012. Available online: https: / / econpapers.repec.org/scripts/redir.pf?u=https $\% 3 \mathrm{~A} \% 2 \mathrm{~F} \% 2 \mathrm{Fwww}$. cesifo.org\%2FDocDL\%2Fcesifo1_wp4052.pdf;h=repec:ces:ceswps:_4052 (accessed on 1 December 2021).

45. Cherbonnier, F.; Gollier, C. Risk-Adjusted Social Discount Rates. Energy J. 2022, 43. [CrossRef]

46. IPCC. Climate Change 2014: Mitigation of Climate Change; Cambridge University Press: Cambridge, UK; New York, NY, USA, 2014; ISBN 978-1-107-05821-7.

47. Moore, M.A.; Vining, A.R. The Social Rate of Time Preference and the Social Discount Rate; Mercatus Center at George Mason University: Arlington, VA, USA, 2018.

48. Burgess, D.F.; Zerbe, R.O. Appropriate Discounting for Benefit-Cost Analysis. J. Benefit-Cost Anal. 2011, 2. [CrossRef]

49. Spackman, M. Social Discounting and the Cost of Public Funds: A Practitioner's Perspective. J. Benefit-Cost Anal. 2020, 11, $244-271$. [CrossRef]

50. Berrens, R.P.; Bohara, A.K.; Jenkins-Smith, H.C.; Silva, C.L.; Weimer, D.L. Information and Effort in Contingent Valuation Surveys: Application to Global Climate Change Using National Internet Samples. J. Environ. Econ. Manag. 2004, 47, 331-363. [CrossRef]

51. Luckert, M.K.; Adamowicz, W.L. Empirical Measures of Factors Affecting Social Rates of Discount. Environ. Resour. Econ. 1993, 3, 1-21. [CrossRef]

52. Chapman, G.B. Time Preferences for the Very Long Term. Time Judgement Decis. Mak. 2001, 108, 95-116. [CrossRef]

53. Frederick, S. Measuring Intergenerational Time Preference: Are Future Lives Valued Less? J. Risk Uncertain. 2003, 26, 39-53. [CrossRef]

54. Cropper, M.L.; Aydede, S.K.; Portney, P.R. Preferences for Life Saving Programs: How the Public Discounts Time and Age. J. Risk Uncertain. 1994, 8, 243-265. [CrossRef]

55. Wang, H.; He, J. Implicit Individual Discount Rate in China: A Contingent Valuation Study. J. Environ. Manag. 2018, 210, 51-70. [CrossRef] [PubMed]

56. Weitzman, M.L. Gamma Discounting. Am. Econ. Rev. 2001, 91, 260-271. [CrossRef]

57. Almansa, C.; Martínez-Paz, J.M. What Weight Should Be Assigned to Future Environmental Impacts? A Probabilistic Cost Benefit Analysis Using Recent Advances on Discounting. Sci. Total Environ. 2011, 409, 1305-1314. [CrossRef]

58. Drupp, M.A.; Freeman, M.C.; Groom, B.; Nesje, F. Discounting Disentangled. Am. Econ. J. Econ. Policy 2018, 10, 109-134. [CrossRef]

59. Meerding, W.J.; Bonsel, G.J.; Brouwer, W.B.; Stuifbergen, M.C.; Essink-Bot, M. Social Time Preferences for Health and Money Elicited with a Choice Experiment. Value Health 2010, 13, 368-374. [CrossRef] [PubMed]

60. Howard, G. Discounting for Personal and Social Payments: Patience for Others, Impatience for Ourselves. J. Environ. Econ. Manag. 2013, 66, 583-597. [CrossRef]

61. Howard, G.; Whitehead, J.C.; Hochard, J. Estimating Discount Rates Using Referendum-Style Choice Experiments: An Analysis of Multiple Methodologies. J. Environ. Econ. Manag. 2021, 105, 102399. [CrossRef]

62. Ubfal, D. How General Are Time Preferences? Eliciting Good-Specific Discount Rates. J. Dev. Econ. 2016, 118, 150-170. [CrossRef]

63. Robberstad, B. Estimation of Private and Social Time Preferences for Health in Northern Tanzania. Build. Trust Value Health Syst. Low- Middle- Income Ctries. 2005, 61, 1597-1607. [CrossRef]

64. Stevens, T.H.; DeCoteau, N.E.; Willis, C.E. Sensitivity of Contingent Valuation to Alternative Payment Schedules. Land Econ. 1997, 73, 140-148. [CrossRef]

65. Egan, K.J.; Corrigan, J.R.; Dwyer, D.F. Three Reasons to Use Annual Payments in Contingent Valuation Surveys: Convergent Validity, Discount Rates, and Mental Accounting. J. Environ. Econ. Manag. 2015, 72, 123-136. [CrossRef]

66. Frederick, S.; Loewenstein, G.; O’Donoghue, T. Time Discounting and Time Preference: A Critical Review. J. Econ. Lit. 2002, 40, $351-401$. [CrossRef]

67. Loewenstein, G.; Prelec, D. Anomalies in Intertemporal Choice: Evidence and an Interpretation. Q. J. Econ. 1992, 107, 573-597. [CrossRef]

68. Venkatachalam, L. The Contingent Valuation Method: A Review. Environ. Impact Assess. Rev. 2004, 24, 89-124. [CrossRef]

69. Tukey, J.W. Exploratory Data Analysis; Addison-Wesley Series in Behavioral Sciences; Addison-Wesley Pub. Co.: Boston, MA, USA, 1977.

70. GUS-Bank Danych Lokalnych. Available online: https://bdl.stat.gov.pl/BDL/start (accessed on 2 November 2021).

71. Joshi, A.; Kale, S.; Chandel, S.; Pal, D.K. Likert Scale: Explored and Explained. Br. J. Appl. Sci. Technol. 2015, 7, 396. [CrossRef] 
72. Rodríguez, E.M.M.; Lacaze, M.V.; Lupín, B. Contingent Valuation of Consumers' Willingness-to-Pay for Organic Food in Argentina. In Proceedings of the 12th Congress of the European Association of Agricultural Economists-EAAE, Ghent, Belgium, 26-29 August 2008.

73. Cavanaugh, J.E.; Neath, A.A. The Akaike Information Criterion: Background, Derivation, Properties, Application, Interpretation, and Refinements. Wiley Interdiscip. Rev. Comput. Stat. 2019, 11, e1460. [CrossRef]

74. Kim, S.-I.; Haab, T.C. Temporal Insensitivity of Willingness to Pay and Implied Discount Rates. Resour. Energy Econ. 2009, 31, 89-102. [CrossRef]

75. Hardisty, D.J.; Weber, E.U. Discounting Future Green: Money Versus the Environment. J. Exp. Psychol. Gen. 2009, 138, 329-340. [CrossRef]

76. Jørgensen, S.L.; Olsen, S.B.; Ladenburg, J.; Martinsen, L.; Svenningsen, S.R.; Hasler, B. Spatially Induced Disparities in Users' and Non-Users' WTP for Water Quality Improvements-Testing the Effect of Multiple Substitutes and Distance Decay. Land Use 2013, 92, 58-66. [CrossRef]

77. Breuer, W.; Müller, T.; Sachsenhausen, E. The Determinants of Discounting in Intergenerational Decision-Making; Social Science Research Network: Rochester, NY, USA, 2021.

78. Berry, M.S.; Nickerson, N.P.; Odum, A.L. Delay Discounting as an Index of Sustainable Behavior: Devaluation of Future Air Quality and Implications for Public Health. Int. J. Environ. Res. Public Health 2017, 14, 997. [CrossRef] [PubMed]

79. Moser, C.; Stauffacher, M.; Smieszek, T.; Seidl, R.; Krütli, P.; Scholz, R.W. Psychological Factors in Discounting Negative Impacts of Nuclear Waste. J. Environ. Psychol. 2013, 35, 121-131. [CrossRef]

80. Lewinsohn-Zamir, D. Consumer Preferences, Citizen Preferences, and the Provision of Public Goods. Yale Law J. 1998, 108, 377-406. [CrossRef]

81. Foltyn-Zarychta, M. The Dilemmas of Public vs. Private Goods Discounting for Long-Term Investment Appraisal: The Puzzle of Citizen and Consumer Approaches to Valuation. Folia Oecon. Stetin. 2020, 20, 114-133. [CrossRef]

82. Mill, A.G.; van Rensburg, T.M.; Hynes, S.; Dooley, C. Preferences for Multiple Use Forest Management in Ireland: Citizen and Consumer Perpectives. Ecol. Econ. 2007, 60, 642-653. [CrossRef]

83. Ari, I.; Koc, M. Philanthropic-Crowdfunding-Partnership: A Proof-of-Concept Study for Sustainable Financing in Low-Carbon Energy Transitions. Energy 2021, 222, 119925. [CrossRef] 